\title{
Investigating self-directed learning and technology readiness in blending learning environment
}

\author{
Shuang Geng ${ }^{1}$, Kris M. Y. Law ${ }^{2^{*}}$ (D) and Ben Niu'
}

\author{
* Correspondence: Kris.law@deakin. \\ edu.au \\ ${ }^{2}$ School of Engineering, Deakin \\ University, Geelong, Australia \\ Full list of author information is \\ available at the end of the article
}

\begin{abstract}
Blended Learning (BL) creates a 'rich' educational environment with multiple technologyenabled communication forms in both face-to-face and online teaching. Students' characteristics are closely related to the learning effectiveness in the BL environment. Students' ability to direct themselves in learning and to utilise learning technologies can affect student learning effectiveness. This study examined the impacts of self-directed learning, technology readiness, and learning motivation on the three presences (social, teaching, cognitive) among students undertaking subjects in BL and non-BL (NBL) settings. The results indicated that the BL environment provides good facilitation for students' social involvement in the class. Student technology readiness plays a stronger role in impacting the teaching presence in a BL environment than NBL environment. These findings imply that a proper BL setting creates a cohesive community and enhances collaborations between students. Prior training of learning technologies can potentially enhance students' teaching presence.
\end{abstract}

Keywords: Blended learning, Self-directed learning, Technology readiness, Motivation, Community of inquiry

\section{Highlights}

- Blended Learning (BL) has been advocated in higher education section.

- This study investigates the impacts of self-directed learning, technology readiness, and learning motivation on students' perception of three presences (social, teaching, cognitive).

- Results show that students in the BL group achieve significantly higher social presence than students in the NBL group.

- Self-directed learning has significant and direct impacts on the cognitive presence of students in the BL setting.

- Student technology readiness plays a stronger role in impacting the teaching presence in BL environment than NBL environment.

- Social presence has significant impacts on the other two presences. 


\section{Introduction}

Blended Learning (BL) creates a rich educational environment enabling various forms of communication by combining face-to-face learning with technologically enhanced learning so that instruction and learning occur both in the classroom and online (Collis \& Moonen, 2012). A blended learning course lies between a continuum anchored at opposite ends by entirely face-to-face and fully online learning environments (Rovai \& Jordan, 2004). The effective integration of the face-to-face and Internet Technology (IT) components determines the quality of course design so that blended learning is not just an add-on to the existing dominant approach or method (Garrison \& Kanuka, 2004). In the higher education context, the interaction and sense of engagement in a community provide the conditions for free and open dialogue, critical debate, negotiation and agreement, which are the hallmark of effective education (Garrison \& Cleveland-Innes, 2005). The Community of Inquiry (CoI) framework is widely used in online learning research and pedagogy for enriching students' learning experience (Annand, 2011). The three presences in the CoI framework, social presence, cognitive presence, and teaching presence integrally promote social and intellectual interactions among participants and materials and, thereby, fruitful learning outcomes (Annand, 2011; Garrison, Anderson, \& Archer, 2000). The three presences also offer a convenient instrument with three dimensions to assess the students' perceptions of the learning experience and reflect their learning effectiveness.

In the online learning scenarios, where the structure of an online curriculum is mostly automatic (Khan, 2009), students have more flexibility in deciding when, how and with what content and activities they engage (Milligan \& Littlejohn, 2014). This flexibility requires students to monitor and adjust their behaviour and actions concerning the specific learning context (Zimmerman, 2000). Students are aware of their learning responsibility in themselves instead of an external source, such as a teacher (Demir, 2015). A self-directed learner tends to actively engage in the learning processes, such as acquiring information, planning and evaluating the learning activities. Active learning strategies can increase students' participation and improve the learning process and performance (Freeman et al., 2014; Yilmaz, 2016). However, not much empirical evidence is available in the extent literature regarding the impact of self-direct learning in the blended learning setting.

Technology readiness is another critical dimension connected with students' learning in the blended learning environment. The emergence of various computer technologies enables the usage of multimedia content and multimedia communication (Horton, 2006) for education, and provides anywhere, anytime access to the learning content. Existing studies have been focused on students' adoption of learning technologies and the determinant factors, for instance, personal innovation, perceived usefulness, performance expectancy, effort expectancy, social influence, perceived playfulness, self-management of learning, using the Technology Acceptance Model (TAM) and Unified Theory of Acceptance and User of Technology (UTAUT) (Liu, Li, \& Carlsson, 2010; Wang, Wu, \& Wang, 2009). Students' technology readiness refers to their propensity to embrace new technologies for accomplishing goals in learning (Parasuraman, 2000). Studies on e-learning readiness found that students' level of e-learning readiness can influence of level of success in e-learning (Moftakhari, 2013; Piskurich, 2003). Today, most university students are digital natives and use technology well (Prensky, 2001). However, 
the utilisation of learning technologies combined with traditional in-class teaching is still a developing teaching approach for university instructors and students, and predictors of learning effectiveness remain unclear (Hao, 2016).

Besides, though there are some research works on technology enhanced learning, there exists no well agreed results. Studies have shown different results which contains positive relationship, negative relationships, and no significant relationships between using the internet for course material and student learning outcome (Gulek \& Demirtas, 2005; Shouping \& Kuh, 2001; Sana, Weston, \& Cepeda, 2013).

To fill this gap, it necessary to explore the impact of technology readiness and individual behaviour on academic performance in the blended learning context. While motivation is one of the success factors for online learning (Lim, 2004), for its significant impact on learner attitudes and learning behaviour in traditional educational environments (Fairchild, Jeanne-Horst, Finney, \& Barron, 2005).

The purpose of this paper is two-folded. First, grounded on the Theory of Planned Behavior (TPB) which posits individual behaviour is driven by behaviour intentions, and social cognitive theory, this study explores the deeper connections between self-directed learning, technology readiness, and student motivation, to understand their integral effects on the three presences of $\mathrm{CoI}$ (teaching, cognitive and social), thus expanding the literature in blended learning research and examining its influencing factors which have not been sufficiently explored.

Second, considering the lack of studies addressing the interdependencies in different settings, our study compares the interdependences in blended learning and non-blended learning, with the aim to provide empirical evidence and insights for instructors to adopt a proper instructional strategy in online, and offline teaching.

The subsequent sections of this paper discuss the related literature supporting the proposed research model. The research hypotheses and data collection method are then presented. The results and findings are reported, and conclusions are drawn.

\section{Literature review}

\section{Blended learning}

Blended Learning (BL) integrates face-to-face learning with online learning and enables asynchronous teaching and learning (Graham, 2013). Littlejohn and Pegler (2007) used "strong" and "weak" blends to indicate the various amounts of e-learning. Through a variety of online learning technologies, such as online discussion forums, BL enables communication among learners and between learners and teachers. Effective integration of traditional classroom teaching with e-learning provides support to asynchronous and cooperative learning among students. Achieving a balance between classroom and online learning is necessary as students still value the face-to-face opportunities to receive feedback in BL setting (Vanslambrouck, Zhu, Lombaerts, Philipsen, \& Tondeur, 2018).

There have been a number of studies carried out on the adoption of effective educational technology (Findik \& Ozkan, 2013; Mtebe \& Raisamo, 2014). Graham et al. (2013) identifies that strategy, structure, and support are three key factors for BL adoption. Challenges to the design of effective BL course have been classified by Boelens, De Wever, and Voet (2017) into four types, which includes incorporating teaching flexibility, facilitating students' interaction, facilitating learning process, and fostering affective learning climate. Porter, 
Graham, Bodily, and Sandberg (2016) found that innovation adoption strategy affects how institutional strategy, structure, and support decisions facilitate or impede BL adoption. Besides innovation adoption strategy, institution blocks, teachers and students also determine the key factors promoting successful BL. Institutional blocks including organisational readiness, adjacent technical resources, motivated faculty, professional development for teachers and students' maturity and readiness for blending learning are all concerns (Tabor, 2007; Vaughan, 2007). Therefore, the learning experience of students in BL courses is presumed to be influenced by a different set of factors from traditional classes.

\section{Theory of planned behaviour and social cognitive theory}

The Theory of Planned Behavior (TPB) argues that individual attitude toward the behaviour can determine individual behaviour (Ajzen, 1991). Social Cognitive Theory (SCT) explains human behaviour through three interacting determinants: cognitive, affective and biological events; environment, and behaviour (Compeau \& Higgins, 1995). TPB and SCO are widely applied in studies to explain individual behaviour related to technology use (Barnard-Bark, Burley, \& Crooks, 2010; Compeau \& Higgins, 1995).

Personal factors such as own intentions and attitudes are the main focus of this study. Students' self-directed learning here refers to students' perceptions of their independent learning, their sense of responsibility in their learning and their initiative in learning. Self-directed learning shares some common features with self-regulated learning. Broadbent (2017) found that self-regulated learning has different predictive value among online learners and BL learners. Technology readiness refers to individual attitudes toward new technologies. Students' perceptions in CoI to a certain extent reflect the learning effectiveness or learning experience of students in a course. Based on TPB and SCT, self-directed learning and technology readiness are postulated to be able to differently drive the students' learning behaviour, with different learning experience and perceptions of CoI.

\section{Community of inquiry}

A community is essential to support collaborative learning. The framework of the Community of Inquiry (CoI) developed by Garrison et al. (2000) provides necessary guidance for the employment of instructional technologies to support the BL environment. There are three dimensions in CoI framework, which include social presence, cognitive presence, and teaching presence. Social presence represents the ability of learners to behave socially and emotionally. The student group cohesiveness and interaction is strongly correlated with the learning outcomes (Hwang \& Arbaugh, 2006; Williams, Duray, \& Reddy, 2006), which are essential in a BL design. Cognitive presence refers to the extent that learners can absorb meaning in the process of reflection and discourse. Cognitive presence involves practical inquiry (Garrison \& Arbaugh, 2007), interaction and critical thinking skills of the participants (Duphorne \& Gunawardena, 2005). Teaching presence refers to the design, facilitation and direction of student learning and thinking processes (Garrison et al., 2000). Students' sense learning community and satisfaction are influenced by pedagogical design of BL course (Shea, Li, Swan, \& Pickett, 2005), and particularly teaching presence (Arbaugh, 2007).

These three presences are closely interconnected (Akyol \& Garrison, 2008; Shea et al., 2010). Teaching presence makes the student become more actively thinking about 
the learning content and involvement in student learning discussion, thus improves cognitive and social presences (Ke, 2010). Social presence can also predict student cognitive presence (Archibald, 2010). However, the interrelationships are dynamic in a different learning setting between the three presences and requires further exploration.

\section{Self-directed learning and learning effectiveness}

Self-directed learning (SDL) refers to the psychological processes of learners that purposively direct themselves to gain knowledge and understand how to solve problems (Long, 1994). Self-directed learners usually more actively participate in learning tasks such as reading online learning material, completing classroom tasks, planning and evaluating milestones of learning. High-level self-management is important in SDL and learners to need to adopted different strategies in dealing with various problems (Lee \& Teo, 2010). Similar to self-regulated learning, SDL also emphasises on goal setting and choice making, which are crucial to student collaborative learning (Gilbert \& Driscoll, 2002). The difference between SDL and self-regulated learning lays in their required skills. The constructs of SDL are at the macro level, and constructs of self-regulated learning belong to micro-level (Jossberger, Brand-Gruwel, Boshuizen, \& Wiel, 2010).

Self-directed learners tend to search the online learning platform for resources. Research on self-directed learning with technology (SDLT) (Teo et al., 2010) revealed that students' perceptions of collaborative learning can enhances students SDL. Student SDL processes contribute to the use of Internet communication technology for collaborative learning (Lee, Tsai, Chai, \& Koh, 2014). The role of self-regulated learning discussed in the CoI framework was found to be positively related to students' perceived CoI and affective outcomes (Cho, Kim, \& Choi, 2017; Garrison \& Akyol, 2015). Learners that are skilled at SRL will visit course materials more frequently (Kizilcec, Pérez-Sanagustín, \& Maldonado, 2017). Despite that existing studies reveals of impact of SDL on learning effectiveness, how SDL enhances or undermine students' perception of CoI remains unexplored.

\section{Technology readiness and learning effectiveness}

Technology-readiness refers to one's willingness to leverage new technologies in performing tasks (Parasuraman, 2000). Web-based technologies, though well established, still face the challenge of being readily accepted when introduced to a new application setting. Compared to traditional classroom learning, students' readiness to accept and utilise web-based learning resources varies across individuals. Students' attitude toward technology-based applications reflects their technology readiness in the learning scenarios. Cheon, Lee, Crooks, and Song (2012) found that college students' attitude positively influences their intention to adopt mobile learning. For the blended learning context, using online learning sources is compulsory. Otherwise, it will be not possible to get the desired learning result.

As mentioned earlier, the use of learning technologies has different impacts on students' learning outcomes which may be caused by contextual and cognitive factors (Hong, Hwang, Liu, \& Chen, 2014). BL environment was found to increase student attendance and learning satisfaction in science education (Stockwell, Stockwell, 
Cennamo, \& Jiang, 2015). Moreover, using online course material can enhance student intellectual development (Shouping \& Kuh, 2001). On the other hand, some students reported that their course grades decrease as they spend too much time on online course material. These diverse research results reveal the interest and importance of exploring the readiness for learning technologies and its influences on students' perceptions and behaviours. Parasuraman (2000) developed and validated a measurement scale, called the Technology Readiness Index (TRI) for technology readiness, which consisted of 28 items, clustered into four categories: optimism, innovativeness, discomfort, and insecurity. These four categories integrally reflect the individual attitude toward new technologies in the learning process.

\section{Learning motivation}

Learning motivation is the process whereby goal-directed activity is instigated and sustained, and it is reflected in personal investment and in cognitive, emotional, and behavioural engagement in learning activities (Fredricks, Blumenfeld, \& Paris, 2004). Research on students' learning reveals that self-efficacy and goal settings are highly related to learning motivation (Che-Ha, Mavondo, \& Mohd-Said, 2014; Law \& Breznik, 2017; Law, Lee, \& Yu, 2010; Ngan \& Law, 2015). Motivation is an essential factor in the completion of both online and in-class learning activities. Although various educational research emphasises on learning motivation, its relationships between self-directed learning and technology readiness have not been sufficiently explored in the blended learning setting.

\section{Research questions}

The BL environment offers a different setting with multiple media for teaching, communication, discussion and evaluation. The evidence from the existing literature highlights the importance of self-monitored learning behaviours and technology readiness in the online learning environment. The balance between online learning and in-class learning is relatively hard to achieve and one of the challenges for BL course design. Exploring the impacts of self-directed learning and technological readiness on students' motivation and perceptions of $\mathrm{CoI}$ can deepen the understanding of blended learning course pedagogy design. The comparison between blended learning and non-blended learning course students can further provide insights into special needs and behaviours of students in a blended learning environment. Therefore, the research questions of this study are:

Q1. Is there difference between students attending BL courses and student attending traditional classroom course in their perception of CoI?

Q2. Do self-directed learning and technology readiness have equal influences on students' motivation and perception of CoI between BL and traditional classroom course?

\section{Methodology}

\section{Research hypotheses}

A concept model is proposed, as illustrated in Fig. 1, which presents hypothesised relationships between self-directed learning, technology readiness, motivation and students' perceptions of CoI. The conceptual model is also applied to examine the 


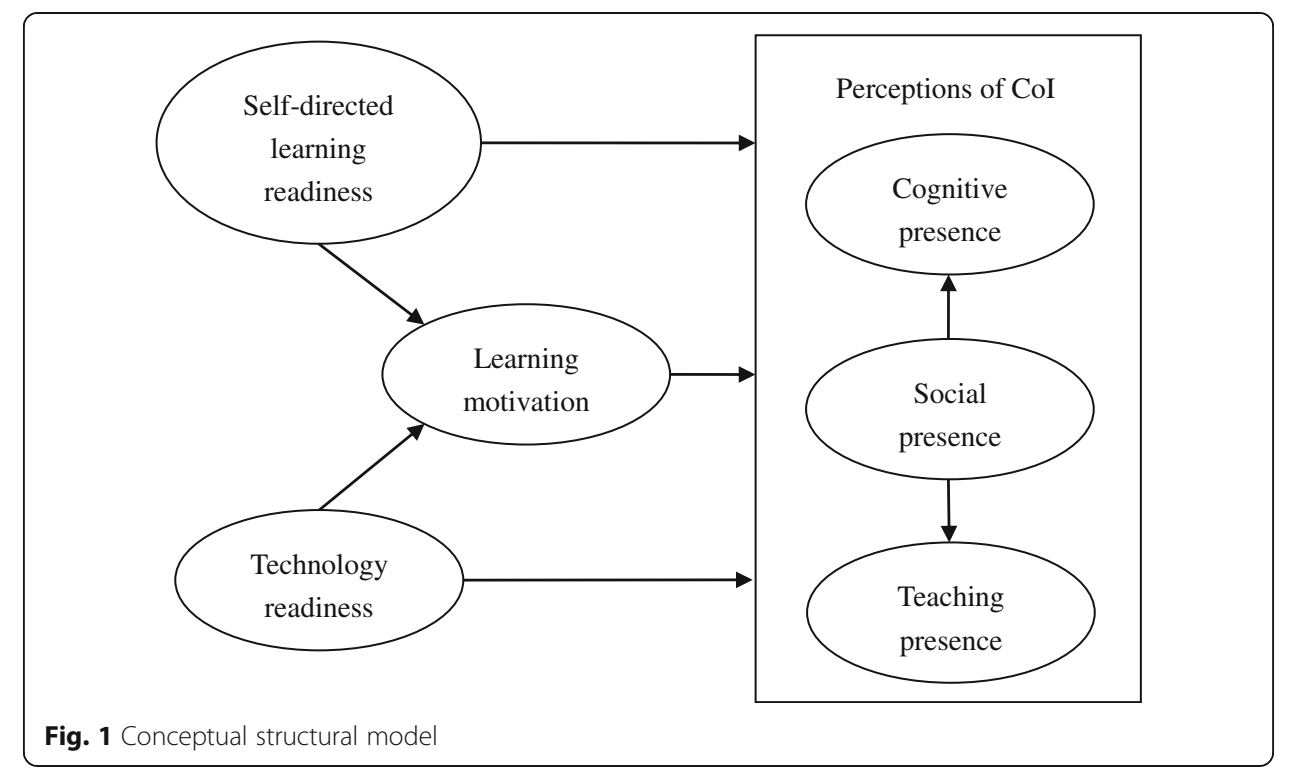

differences of interrelationships between BL student groups and non-BL student groups. In this section, hypotheses are developed in response to our research questions.

\section{Impacts of self-directed learning}

Self-directed learners actively engage in the learning process and can adopt proper learning strategies according to the learning setting. A technology-rich learning environment can provide students with great opportunities and abilities to be selfdirected in their learning (Fahnoe \& Mishra, 2013). The blended learning teaching context offers students opportunities to interact with instructors and classmates face-to-face through discussion and self-controlled access to multimedia learning content. Self-directed aspects of learning (the choice of what, when, and how long to study) have significant repercussions in the effectiveness of users' learning efforts (Tullis \& Benjamin, 2011). Facing uncertainties in the online learning context, students need to adjust or formulate their own best learning strategies. It is anticipated that highly self-directed learners are involved in learning activities online more actively by asking questions and joining in discussions, thus have a stronger sense of CoI than students with low self-directedness. Self-directed students also have a stronger willingness to achieve learning goals. Therefore, we put forward the following hypotheses:

H1.Student self-directed learning readiness positively correlates with students' perception of $\mathrm{CoI}$

H2. Self-directly learning positively correlates with learning motivation

\section{Impacts of technology readiness}

Students with higher levels of technology readiness hold a positive attitude toward technological learning media and innovative platforms for communication. Students with a sense of discomfort and insecurity in adopting technologies may take a longer 
time to become efficient users of online learning platforms. The blended learning context requires students to complete the online learning tasks together with in-class learning activities. Student factors such as self-efficacy in using the computer, motivation toward t-learning are efficient to fulfil the online course prerequisites, (Demir, 2015; Hao, 2016; Moftakhari, 2013). Previous studies have evaluated students' readiness for specific learning technologies or platforms (Cheon et al., 2012; Shouping \& Kuh, 2001). Students' attitude toward the broad collection of new technology products includes optimism, innovativeness, discomfort, and insecurity (Parasuraman \& Colby, 2015). Students with optimism and innovativeness toward learning technologies are more willing to adopt the online learning strategy than students with discomfort and insecurity. Therefore, we put forward following these hypotheses:

H3. Student Technology readiness positively correlates with students' perception of $\mathrm{CoI}$

H4. Technology readiness positively correlates with learning motivation

\section{Impacts of learning motivation}

It is believed learning motivation can influence students' attitudes and behaviour in educational environments (Fairchild et al., 2005). In the online learning context, strongly motivated students are more likely to watch videos and read the online learning material compared to students who are less motivated. Thus, motivation is mainly related to student learning effectiveness in the blended learning setting. Therefore, our fifth hypothesis is:

H5. Student learning motivation correlates with students' perception of CoI

\section{Relationships between three presences}

Students, who behave more socially and emotionally in mediated communication, can interact with group members more efficiently, thus enhance the group cohesiveness. Socially communication can also facilitate the communications between teachers, platforms and students. In the interactions, students can develop critical thinking skills to deal with various types of opinions and reflect on the learning content. Therefore, we hypothesise that:

H6. Social presence positively correlates with cognitive and teaching occurrences H6a. Social presence positively correlates with teaching presence H6b. Social presence positively correlates with the cognitive presence

\section{Blended learning context for engineering students}

Various BL models have been reported to be useful in previous studies (Dziuban \& Moskal, 2001; Martyn, 2003). Blended learning undergraduate courses were designed for engineering students in a university in Hong Kong. Engineering students are expected to be more adaptive to practical situations according to their abilities (Law \& Geng, 2018). Individual differences in these learning attributes pose challenges to engineering education whose aim is to provide instruction about "real-world" engineering 
design and operations, provide training in critical and creative thinking skills, provide graduates who are conversant with engineering ethics and connect between technology and society (Felder, Woods, Stice, \& Rugarcia, 2000). The engineering management subjects, including innovation and entrepreneurship, and the business process are developed with a mixture of collaborative learning, project-based learning (PBL), team/peer learning, and independent learning. An online learning management system (LMS), as shown in Fig. 2, was adopted and integrated with face-to-face in-class teaching. The primary learning objectives of these engineering management subjects are to prepare engineering students with basic understanding of engineering management concepts and the relevant techniques, tools and skills, while the application of knowledge and team skills are also emphasised. The LMS offers students online learning materials, and chapter-end exercises according to the predefined course outline. Students can, therefore, learn at their own pace. Videos of real-life case studies are also available on the LMS, to provide students with further elaboration on the learnt concepts.

Elements in this course, include classroom teaching, E-learning, workshop in class (the practice of learnt knowledge, and peer learning on specific topics such application of assessing and analytical techniques), group projects (peer learning, use of knowledge, sharing of experience, and reflective learning). This arrangement of blended components in the course is to keep students motivated and on-track, while they can learn interactively (interactivity) in the classroom, collaboratively in workshops and in group projects with peers. They would also be able to develop good communication with both peers and teachers in person, or via various reflections. An agreed assessment plan also shows the learning progress of the students, as well as to pinpoint the areas for improvement in the learning journey. To summarise, the assessment consists of Individual assignments, tests and in-class activities (50\%), Group, peer learning projects (30\%), Reflections on individual and peer learning (20\%).

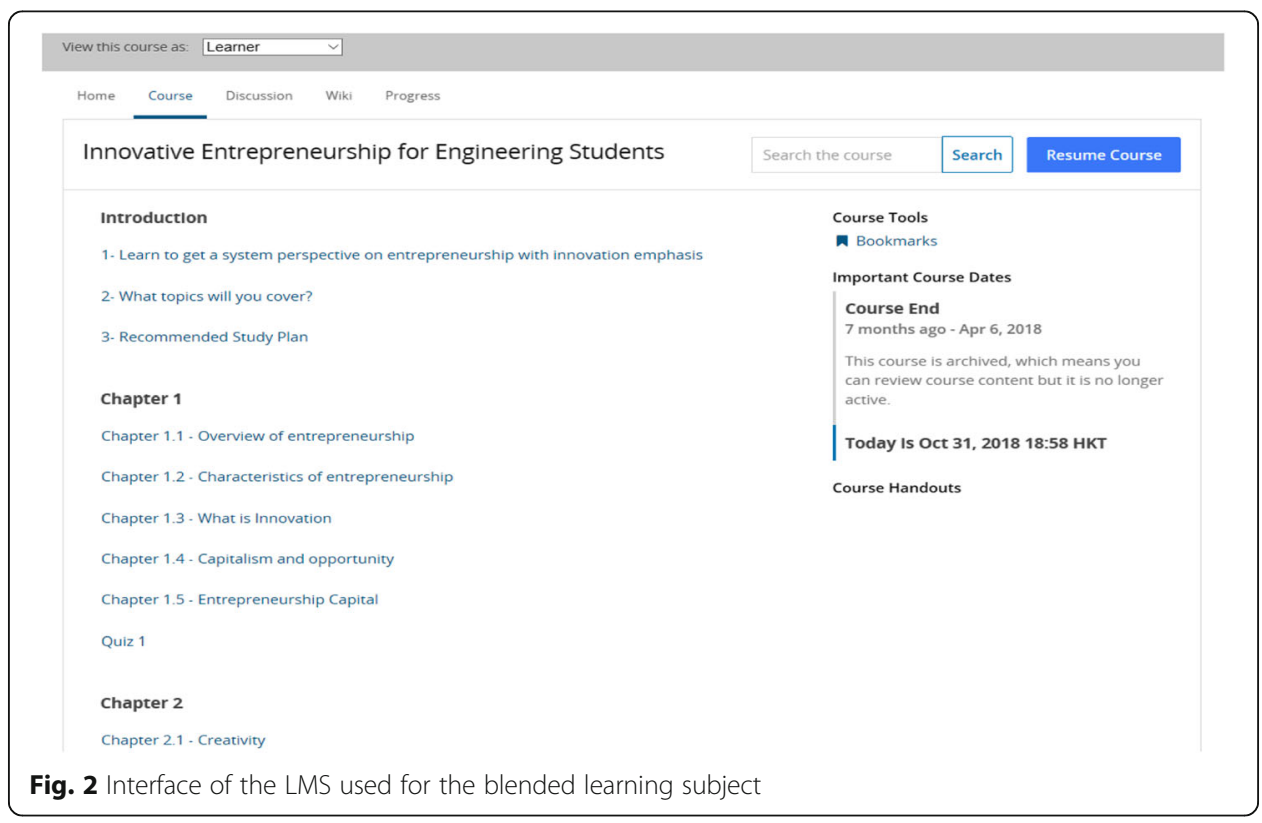




\section{Data collection}

\section{Instrument}

A questionnaire was developed corresponding to the factors in our model (see Fig. 1), using 5 -point Likert scales ( $1=$ strongly disagree; $5=$ strongly agree). The questionnaire has two parts, and the first part contains four scales from existing studies:

1) The learning motivation scale was used in Law and Geng (2018) on student innovativeness and handedness.

2) Self-directed learning with technology (Lee et al., 2014; Teo et al., 2010) for measuring young students' perceptions of self-directed learning with the support of technology.

3) Technological readiness index (Parasuraman, 2000; Parasuraman \& Colby, 2015) measures people's propensity to embrace and use new technologies in four dimensions: optimism, innovativeness, discomfort, and insecurity.

4) Modified CoI instrument consists of teaching presence, social presence, and cognitive presence (Arbaugh et al., 2008).

The second part consists of the personal particulars of respondents, such as gender, age, discipline, and year of study. A pilot study was carried among ten volunteer students, to confirm the validity of the questionnaire, before data collection. For the data collection, we invited voluntary participation from students who were in the course. The data collection was carried out near the end of the semester. There were 96 valid samples received from the Blended Learning (BL) student group out of 102 responses and 111 valid samples received from Non-BL (NBL) student group out of 121 responses.

\section{Measurement model estimation}

Partial Least Squares (PLS) (Henseler \& Sarstedt, 2013) was adopted to estimate the proposed model (Fig. 1). The unidimensionality of six blocks of constructs (learning motivation, self-directed learning readiness, technology readiness, social presence, cognitive presence, teaching presence) and the results contained in the outer model were firstly tested. Cronbach's alpha, Dillon-Goldsteim's rho, Composite reliability and AVE were used to check the unidimensionality.

As presented in Table 1, the Cronbach's alpha, Dillon-Goldsteim's rho, Composite reliability for all the constructs are above 0.70 (Sanchez, 2013). The AVE values are above the threshold of 0.50 (Fornell \& Larcker, 1981) among all the constructs. Therefore, the construct validity of the measurements fulfil the requirement.

Table 1 Unidimensionality of constructs

\begin{tabular}{|c|c|c|c|c|c|}
\hline Latent variable & MVs & $\begin{array}{l}\text { Cronbach's } \\
\text { alpha }\end{array}$ & $\begin{array}{l}\text { Dillon-Goldstein's } \\
\text { rho }\end{array}$ & $\begin{array}{l}\text { Composite } \\
\text { reliability }\end{array}$ & AVE \\
\hline Learning motivation (LM) & 4 & 0.754 & 0.757 & 0.843 & 0.574 \\
\hline $\begin{array}{l}\text { Self-directed learning } \\
\text { readiness }(\mathrm{SDL})\end{array}$ & 3 & 0.703 & 0.713 & 0.834 & 0.626 \\
\hline Technology readiness (TRD) & 4 & 0.814 & 0.825 & 0.878 & 0.643 \\
\hline Social presence (SP) & 4 & 0.786 & 0.790 & 0.862 & 0.611 \\
\hline Cognitive presence (CP) & 6 & 0.858 & 0.859 & 0.894 & 0.586 \\
\hline Teaching presence (TP) & 5 & 0.842 & 0.850 & 0.888 & 0.613 \\
\hline
\end{tabular}


The outer weights, loadings and communality measures shown in Table 2 demonstrate the convergent validity as item loadings are higher than threshold (Factor loadings $>0.7$, communalities $>0.5$ ). The discriminant validity condition was also fulfilled as square root of the AVE for each construct is larger than its correlation with other construct as shown in Table 3 (Chin, 1998; Fornell \& Larcker, 1981).

\section{Results}

\section{Student demographics}

A total of 102 engineering students participating in BL courses and 121 engineering students participating in non-BL courses filled in the questionnaire and provided a total of 207 valid answers. An overview of these participants is presented in Table 4.

The results obtained using One-way ANOVA indicate that gender, year and age of the students do not influence the results of six constructs. Therefore, participants were treated as a single group in our analysis.

Table 2 The outer model estimation

\begin{tabular}{|c|c|c|c|c|}
\hline Latent variable & Manifest Variable & Outer weight & Factor loadings & Communality \\
\hline \multirow[t]{4}{*}{ Learning motivation (LM) } & LM1 & 0.295 & 0.752 & 0.566 \\
\hline & LM2 & 0.313 & 0.784 & 0.615 \\
\hline & LM3 & 0.333 & 0.731 & 0.534 \\
\hline & LM8 & 0.380 & 0.762 & 0.581 \\
\hline \multirow{3}{*}{$\begin{array}{l}\text { Self-directed learning } \\
\text { readiness (SDL) }\end{array}$} & SD4 & 0.400 & 0.781 & 0.610 \\
\hline & SD6 & 0.481 & 0.826 & 0.682 \\
\hline & SD9 & 0.380 & 0.765 & 0.585 \\
\hline \multirow[t]{4}{*}{ Technology readiness (TRD) } & TRD1 & 0.282 & 0.720 & 0.518 \\
\hline & TRD3 & 0.285 & 0.826 & 0.682 \\
\hline & TRD4 & 0.314 & 0.805 & 0.648 \\
\hline & TRD5 & 0.363 & 0.851 & 0.724 \\
\hline \multirow[t]{5}{*}{ Social presence (SP) } & SP2 & 0.295 & 0.712 & 0.507 \\
\hline & SP4 & 0.316 & 0.757 & 0.573 \\
\hline & SP5 & 0.334 & 0.828 & 0.686 \\
\hline & SP6 & 0.333 & 0.823 & 0.677 \\
\hline & CP1 & 0.240 & 0.766 & 0.587 \\
\hline \multirow[t]{5}{*}{ Cognitive presence (CP) } & $\mathrm{CP} 2$ & 0.208 & 0.756 & 0.572 \\
\hline & CP3 & 0.202 & 0.801 & 0.642 \\
\hline & $\mathrm{CP} 4$ & 0.222 & 0.802 & 0.643 \\
\hline & CP5 & 0.206 & 0.733 & 0.537 \\
\hline & CP6 & 0.229 & 0.731 & 0.534 \\
\hline \multirow[t]{5}{*}{ Teaching presence (TP) } & TP1 & 0.212 & 0.708 & 0.501 \\
\hline & TP2 & 0.258 & 0.766 & 0.587 \\
\hline & TP3 & 0.239 & 0.782 & 0.612 \\
\hline & TP4 & 0.280 & 0.836 & 0.699 \\
\hline & TP5 & 0.283 & 0.816 & 0.666 \\
\hline
\end{tabular}


Table 3 Correlation between constructs

\begin{tabular}{|c|c|c|c|c|c|c|}
\hline & $\begin{array}{l}\text { Cognitive } \\
\text { presence(CP) }\end{array}$ & $\begin{array}{l}\text { Learning } \\
\text { motivation } \\
\text { (LM) }\end{array}$ & $\begin{array}{l}\text { Self-directed } \\
\text { learning readiness } \\
\text { (SDL) }\end{array}$ & $\begin{array}{l}\text { Social } \\
\text { presence } \\
\text { (SP) }\end{array}$ & $\begin{array}{l}\text { Teaching } \\
\text { presence } \\
\text { (TP) }\end{array}$ & $\begin{array}{l}\text { Technology } \\
\text { readiness } \\
\text { (TRD) }\end{array}$ \\
\hline $\begin{array}{l}\text { Cognitive } \\
\text { presence (CP) }\end{array}$ & 0.765 & & & & & \\
\hline Learning motivation (LM) & 0.520 & 0.758 & & & & \\
\hline $\begin{array}{l}\text { Self-directed } \\
\text { learning } \\
\text { readiness (SDL) }\end{array}$ & 0.469 & 0.531 & 0.791 & & & \\
\hline $\begin{array}{l}\text { Social presence } \\
\text { (SP) }\end{array}$ & 0.664 & 0.600 & 0.405 & 0.782 & & \\
\hline $\begin{array}{l}\text { Teaching } \\
\text { presence (TP) }\end{array}$ & 0.617 & 0.583 & 0.429 & 0.697 & 0.783 & \\
\hline $\begin{array}{l}\text { Technology } \\
\text { readiness (TRD) }\end{array}$ & 0.315 & 0.410 & 0.417 & 0.323 & 0.423 & 0.802 \\
\hline
\end{tabular}

\section{Difference between BL and NBL groups}

The measurement item mean scores for learning motivation (LM), self-directed learning (SDL), technology readiness (TRD), social presence (SP), cognitive presence $(\mathrm{CP})$, and teaching presence (TP), and their standard deviation among all participating students in both BL and NBL group are presented in Table 5.

As seen from Table 5, the BL group students have higher mean scores for LM, TP, SP than the NBL group. The NBL group has higher mean scores for SDL and CP than the BL group. However, the difference between the mean scores of the BL and NBL groups are minimal. Thus we performed statistical analysis to test the significance of the difference. Independent sample t-testing at a significance level of 0.05 was carried out. The results obtained are shown in Table 6 .

The t-test results show that students participating in BL courses have significantly higher levels of social presence than students attending non-BL classes $(p<0.010)$. This result supports our hypothesis H1a. Students from NBL groups show higher levels of technology readiness than students from the BL group $(p<0.050)$. No significant differences were found for cognitive and teaching presences between the BL and NBL student groups. Thus hypotheses H1b and H1c are not supported.

Table 4 Demographic details of respondents

\begin{tabular}{llllll}
\hline & Blended & & Non-Blended & Total \\
\hline Gender & Male & 66 & Male & 64 & 130 \\
& Female & 30 & Female & 47 & 77 \\
Age & 20 or below & 47 & 20 or below & 11 & 58 \\
& Above 20 & 49 & Above 20 & 100 & 149 \\
Year & $2^{\text {nd }}$ year & 32 & $2^{\text {nd }}$ year & 2 & 34 \\
& $3^{\text {rd }}$ year & 54 & $3^{\text {rd }}$ year & 16 & 70 \\
& $4^{\text {th }}$ year & 10 & $4^{\text {th }}$ year & 93 & 103 \\
Total & & & & 111 & 207 \\
\hline
\end{tabular}


Table $\mathbf{5}$ Overall statistical results

\begin{tabular}{|c|c|c|c|c|c|c|}
\hline & Mean Score & S.D. & BL Mean & S.D. & NBL Mean & S.D. \\
\hline Learning motivation & 3.630 & 0.532 & 3.636 & 0.541 & 3.624 & 0.526 \\
\hline LM1 & 3.780 & 0.748 & 3.725 & 0.773 & 3.826 & 0.727 \\
\hline LM2 & 3.807 & 0.719 & 3.814 & 0.714 & 3.802 & 0.726 \\
\hline LM3 & 3.561 & 0.785 & 3.608 & 0.785 & 3.521 & 0.786 \\
\hline LM4 & 3.623 & 0.760 & 3.676 & 0.747 & 3.579 & 0.772 \\
\hline LM5 & 3.637 & 0.799 & 3.696 & 0.755 & 3.587 & 0.833 \\
\hline LM6 & 3.395 & 0.868 & 3.402 & 0.824 & 3.388 & 0.907 \\
\hline LM7 & 3.650 & 0.813 & 3.588 & 0.813 & 3.703 & 0.813 \\
\hline LM8 & 3.565 & 0.840 & 3.559 & 0.765 & 3.570 & 0.902 \\
\hline Self-directed learning & 3.496 & 0.584 & 3.426 & 0.524 & 3.555 & 0.627 \\
\hline SD1 & 3.520 & 0.915 & 3.441 & 0.929 & 3.587 & 0.901 \\
\hline SD2 & 3.260 & 0.802 & 3.294 & 0.752 & 3.231 & 0.844 \\
\hline SD3 & 3.238 & 0.712 & 3.196 & 0.745 & 3.273 & 0.683 \\
\hline SD4 & 3.466 & 0.793 & 3.412 & 0.825 & 3.512 & 0.765 \\
\hline SD5 & 3.574 & 2.766 & 3.324 & 0.760 & 3.785 & 3.684 \\
\hline SD6 & 3.552 & 0.769 & 3.431 & 0.777 & 3.653 & 0.750 \\
\hline SD7 & 3.601 & 0.837 & 3.569 & 0.802 & 3.628 & 0.867 \\
\hline SD8 & 3.507 & 0.782 & 3.490 & 0.728 & 3.521 & 0.828 \\
\hline SD9 & 3.570 & 0.725 & 3.490 & 0.754 & 3.636 & 0.695 \\
\hline SD10 & 3.668 & 0.715 & 3.608 & 0.692 & 3.719 & 0.733 \\
\hline Technology readiness & 3.569 & 0.515 & 3.562 & 0.587 & 3.574 & 0.448 \\
\hline TRD1 & 3.794 & 0.778 & 3.716 & 0.813 & 3.860 & 0.745 \\
\hline TRD2 & 3.798 & 0.704 & 3.784 & 0.766 & 3.810 & 0.650 \\
\hline TRD3 & 3.592 & 0.771 & 3.559 & 0.896 & 3.620 & 0.649 \\
\hline TRD4 & 3.462 & 0.868 & 3.500 & 0.941 & 3.430 & 0.804 \\
\hline TRD5 & 3.507 & 0.848 & 3.431 & 0.939 & 3.570 & 0.762 \\
\hline TRD6 & 3.399 & 0.879 & 3.324 & 0.903 & 3.463 & 0.857 \\
\hline TRD7 & 3.619 & 0.743 & 3.608 & 0.810 & 3.628 & 0.685 \\
\hline TRD8 & 3.363 & 0.848 & 3.559 & 0.815 & 3.198 & 0.843 \\
\hline Social presence & 3.535 & 0.520 & 3.559 & 0.579 & 3.515 & 0.467 \\
\hline SP1 & 3.534 & 0.709 & 3.500 & 0.728 & 3.562 & 0.694 \\
\hline SP2 & 3.700 & 0.640 & 3.755 & 0.681 & 3.653 & 0.602 \\
\hline SP3 & 3.592 & 0.716 & 3.647 & 0.779 & 3.546 & 0.658 \\
\hline SP4 & 3.668 & 0.709 & 3.618 & 0.797 & 3.711 & 0.625 \\
\hline SP5 & 3.404 & 0.810 & 3.422 & 0.789 & 3.388 & 0.830 \\
\hline SP6 & 3.314 & 0.805 & 3.412 & 0.813 & 3.231 & 0.793 \\
\hline Cognitive presence & 3.542 & 0.576 & 3.518 & 0.611 & 3.562 & 0.548 \\
\hline CP1 & 3.543 & 0.733 & 3.539 & 0.792 & 3.546 & 0.683 \\
\hline $\mathrm{CP} 2$ & 3.498 & 0.753 & 3.382 & 0.784 & 3.595 & 0.714 \\
\hline CP3 & 3.556 & 0.797 & 3.510 & 0.829 & 3.595 & 0.770 \\
\hline CP4 & 3.583 & 0.754 & 3.529 & 0.792 & 3.628 & 0.720 \\
\hline CP5 & 3.525 & 0.776 & 3.490 & 0.767 & 3.554 & 0.785 \\
\hline CP6 & 3.520 & 0.770 & 3.598 & 0.721 & 3.455 & 0.806 \\
\hline CP7 & 3.570 & 0.845 & 3.578 & 0.826 & 3.562 & 0.865 \\
\hline
\end{tabular}


Table 5 Overall statistical results (Continued)

\begin{tabular}{lllllll}
\hline & Mean Score & S.D. & BL Mean & S.D. & NBL Mean & S.D. \\
\hline Teaching presence & 3.611 & 0.861 & 3.733 & 1.032 & 3.507 & 0.671 \\
TP1 & 3.713 & 0.799 & 3.706 & 0.765 & 3.719 & 0.829 \\
TP2 & 3.579 & 0.828 & 3.696 & 0.742 & 3.479 & 0.886 \\
TP3 & 3.498 & 0.890 & 3.627 & 0.832 & 3.388 & 0.925 \\
TP4 & 3.704 & 2.843 & 3.618 & 0.821 & 3.446 & 0.885 \\
TP5 & 3.561 & 0.780 & 3.627 & 0.730 & 3.504 & 0.818 \\
\hline
\end{tabular}

\section{PLS modelling results}

PLS modelling was carried out among the BL group students and the NBL group students separately. The relationship between learning attributes is graphically presented in Fig. 3a and b. The statistical testing results are reported in Tables 7 and 8. All path coefficients between the latent variables in the models are positive, which indicate the positive relationships between each pair of connected factors. Both direct and indirect relationships are examined in the structural model, and the results are also included in Tables 7 and 8. Although PLS path modelling does not provide a widely acceptable global model fit (Chin, 1998; Sarstedt, Ringle, \& Gudergan, 2017), we can still assess the model fit by using the Standardized Root Mean Square Residual (SRMR) and Chi-square methods to the degree of freedom $\left(\mathrm{x}^{2} / \mathrm{df}\right)$. If SRMR value is less than 0.10 or 0.08 , the model fitness is considered as good (Sarstedt et al., 2017). If $\mathrm{x}^{2} / \mathrm{df}$ is less than 5 and larger than 2 when the sample size is larger than 200, the modelling result is considered to be satisfactory (Hafiz \& Shaari, 2013). For both structure models (BL and NBL) in this study, the SRMR values are less than $0.08\left(B L \_S R M R=0.066\right.$, NBL_SRMR $\left.=0.079\right)$. The $x^{2} / \mathrm{df}$ values are also within satisfactory range $\left(\mathrm{NBL}_{-} \mathrm{x}^{2} / \mathrm{df}=2.385, \mathrm{BL}_{-} \mathrm{x}^{2} / \mathrm{df}=4.246\right)$.

\section{Justification of the hypotheses}

An overview of the statistical test results of the hypothesised relationships is presented in Table 9. The different results between the BL and NBL student groups are highlighted.

Table 6 BL group and NBL group mean comparison

\begin{tabular}{llllll}
\hline Variable & $\begin{array}{l}\text { Blended } \\
\text { Mean score }\end{array}$ & $\begin{array}{l}\text { Non-Blended } \\
\text { Mean score }\end{array}$ & $\begin{array}{l}\text { Mean } \\
\text { diff. }\end{array}$ & $\begin{array}{l}F- \\
\text { value }\end{array}$ & Sig. \\
\hline Self-directed learning readiness & 3.426 & 3.555 & -0.129 & 0.003 & 0.956 \\
Technology readiness & 3.562 & 3.574 & -0.0 .12 & 6.100 & $0.014^{*}$ \\
Social presence & 3.559 & 3.515 & 0.044 & 9.363 & $0.002^{* *}$ \\
Cognitive presence & 3.518 & 3.562 & -0.044 & 1.377 & 0.242 \\
Teaching presence & 3.733 & 3.507 & 0.226 & 1.175 & 0.280 \\
Learning motivation & 3.636 & 3.624 & 0.012 & 0.255 & 0.614 \\
\hline ns Not significant & & & & &
\end{tabular}




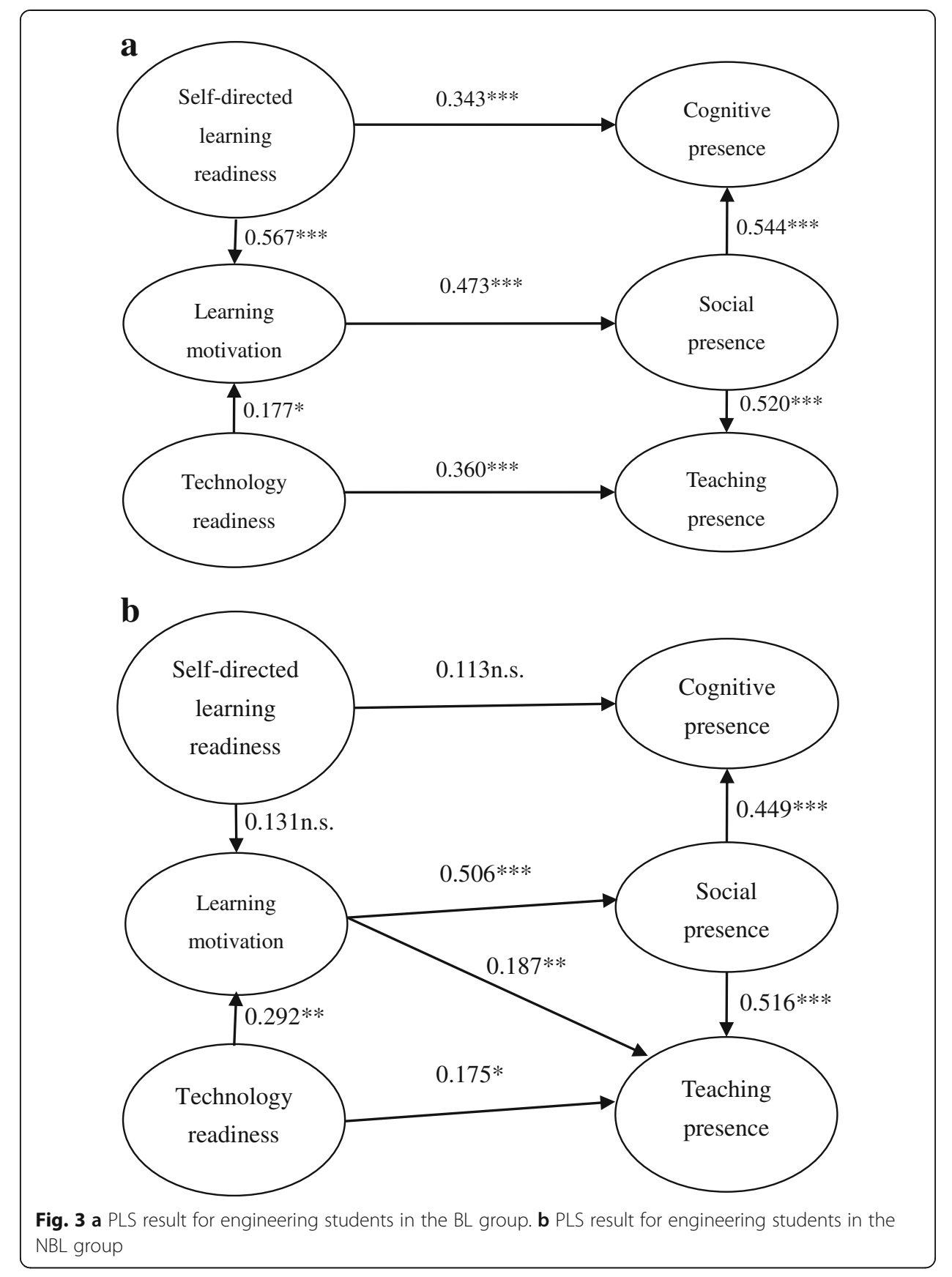

Table 7 Structural path coefficients for the BL group

\begin{tabular}{|c|c|c|c|c|c|c|c|c|}
\hline & \multicolumn{2}{|c|}{$\begin{array}{l}\text { Cognitive } \\
\text { presence (CP) }\end{array}$} & \multicolumn{2}{|c|}{$\begin{array}{l}\text { Social } \\
\text { presence (SP) }\end{array}$} & \multicolumn{2}{|c|}{$\begin{array}{l}\text { Teaching } \\
\text { presence (TP) }\end{array}$} & \multicolumn{2}{|c|}{$\begin{array}{l}\text { Learning } \\
\text { motivation (LM) }\end{array}$} \\
\hline & Direct & Indirect & Direct & Indirect & Direct & Indirect & Direct & Indirect \\
\hline Learning motivation (LM) & & $0.258^{* * *}$ & $0.473^{* * *}$ & & & $0.246^{* * *}$ & & \\
\hline Self-directed learning readiness (SDL) & $0.343^{* * *}$ & $0.146^{* * *}$ & & $0.268^{* * *}$ & & $0.139^{* * *}$ & $0.567^{* * *}$ & \\
\hline Social presence (SP) & $0.544^{* * *}$ & & & & $0.520^{* * *}$ & & & \\
\hline Technology readiness (TRD) & & 0.046 n.s. & & 0.084 n.s. & $0.084^{* * *}$ & 0.043 n.s. & $0.177^{*}$ & \\
\hline
\end{tabular}


Table 8 Structural path coefficients for NBL group

\begin{tabular}{|c|c|c|c|c|c|c|c|c|}
\hline & \multicolumn{2}{|c|}{$\begin{array}{l}\text { Cognitive } \\
\text { presence (CP) }\end{array}$} & \multicolumn{2}{|c|}{$\begin{array}{l}\text { Social } \\
\text { presence (SP) }\end{array}$} & \multicolumn{2}{|c|}{$\begin{array}{l}\text { Teaching } \\
\text { presence (TP) }\end{array}$} & \multicolumn{2}{|c|}{$\begin{array}{l}\text { Learning } \\
\text { motivation (LM) }\end{array}$} \\
\hline & Direct & Indirect & Direct & Indirect & Direct & Indirect & Direct & Indirect \\
\hline Learning motivation (LM) & & $0.455^{* * *}$ & $0.506^{* * *}$ & & $0.187^{* *}$ & $0.679^{* * *}$ & & \\
\hline $\begin{array}{l}\text { Self-directed learning } \\
\text { readiness (SDL) }\end{array}$ & 0.113 n.s. & 0.101 n.s. & & 0.172 n.s. & & 0.137 n.s. & 0.131 n.s. & \\
\hline Social presence (SP) & $0.449^{* * *}$ & & & & $0.516^{* * *}$ & & & \\
\hline Technology readiness (TRD) & & $0.184^{*}$ & & $0.312^{* *}$ & $0.175^{*}$ & $0.248^{* *}$ & $0.292^{* *}$ & \\
\hline
\end{tabular}

ns Not significant

${ }^{* * *} p<0.001,{ }^{* *} p<0.010,{ }^{*} p<0.050$

\section{Discussion}

The structural models of the BL and NBL groups reveal different patterns of interrelationships between the learning attributes and the three presences. Both modelling results highlight the critical roles of self-directed learning, technology readiness, and learning motivation in influencing the learning effectiveness in both BL and NBL settings, and imply how the BL setting can be further modularised for various themes and educational purposes.

Table 9 Hypotheses testing results

\begin{tabular}{|c|c|c|}
\hline Hypotheses & BL group & NBL Group \\
\hline \multicolumn{3}{|l|}{$\begin{array}{l}\text { H1.Student self-directed learning readiness positively correlates } \\
\text { with students' perception of Col }\end{array}$} \\
\hline $\begin{array}{l}\text { H1a.Student self-directed learning readiness positively correlates } \\
\text { with student teaching presence }\end{array}$ & Not support & Not support \\
\hline $\begin{array}{l}\text { H1b.Student self-directed learning readiness positively correlates } \\
\text { with student cognitive presence }\end{array}$ & Support & Not support \\
\hline $\begin{array}{l}\text { H1c.Student self-directed learning readiness positively correlates } \\
\text { with student social presence }\end{array}$ & Not Support & $\begin{array}{l}\text { Not } \\
\text { Support }\end{array}$ \\
\hline H2.Self-directly learning positively correlates with learning motivation & Support & Not support \\
\hline \multicolumn{3}{|l|}{$\begin{array}{l}\text { H3.Student Technology readiness positively correlates with students' } \\
\text { perception of Col }\end{array}$} \\
\hline $\begin{array}{l}\text { H3a.Student Technology readiness positively correlates with } \\
\text { student teaching presence }\end{array}$ & Support & Support \\
\hline $\begin{array}{l}\text { H3b.Student Technology readiness positively correlates with } \\
\text { student cognitive presence }\end{array}$ & Not support & Not Support \\
\hline $\begin{array}{l}\text { H3c.Student Technology readiness positively correlates with } \\
\text { student social presence }\end{array}$ & Not support & Not Support \\
\hline $\begin{array}{l}\text { H4.Technology readiness positively correlates with learning } \\
\text { motivation }\end{array}$ & Support & Support \\
\hline \multicolumn{3}{|l|}{$\begin{array}{l}\text { H5.Student learning motivation correlates with students' } \\
\text { perception of Col }\end{array}$} \\
\hline $\begin{array}{l}\text { H5a.Student learning motivation correlates with students' } \\
\text { perception of teaching presence }\end{array}$ & Not support & Support \\
\hline $\begin{array}{l}\text { H5b.Student learning motivation correlates with students' } \\
\text { perception of cognitive presence }\end{array}$ & Not support & Not Support \\
\hline $\begin{array}{l}\text { H5c.Student learning motivation correlates with students' } \\
\text { perception of social presence }\end{array}$ & Support & Support \\
\hline \multicolumn{3}{|l|}{$\begin{array}{l}\text { H6. Social presence positively correlates with the cognitive and } \\
\text { teaching presences }\end{array}$} \\
\hline H6a. Social presence positively correlates with teaching presence & Support & Support \\
\hline H6b. Social presence positively correlates with the cognitive presence & Support & Support \\
\hline
\end{tabular}


The three presences in BL settings compared to NBL settings

Students in the BL group achieve significantly higher social presence than students in the NBL group. This result indicates that the BL setting surpassed traditional face-to-face teaching setting in socially involving students. The BL course setting provides an open communication environment for students, which allows the students to express themselves socially and emotionally through communication (Garrison et al., 2000). Students can interact with each other and with teachers through online learning platforms besides traditional face-to-face discussion. Social presence provides the cohesion to sustain students' participation and focus. It also creates a sense of belonging, supporting freedom of expression. Therefore, a proper BL setting creates a cohesive community and enhances collaborations between students. The results also support that students in blended courses have higher levels of 'sense of community' than complete online course (Rovai \& Jordan, 2004). The BL setting offers more all-rounded learning facilitation to assist with students' different learning scenarios.

From the results of our study, social presence positively enhances teaching presence and cognitive presence, as shown in the structural models (Fig. 3a and b), confirming the close interrelationships among the presences (Akyol \& Garrison, 2008; Garrison Cleveland-Innes, \& Fung, 2010; Shea et al., 2010). Social presence is found to have a direct effect on the cognitive presence (Shea \& Bidjerano, 2009), whereas teaching presence does not have a direct relationship with the cognitive presence in the BL setting. Cognitive presence allows students to have reflect on their interpretations (Garrison et al., 2000). The communication among student group members during collaborative activities contribute to students' systematic and critical thinking, which is the hallmark of effective higher education. Instructor expertise, instructor support, and students' self-efficacy influence student satisfaction (Diep, Zhu, Struyven, \& Blieck, 2017). In the BL setting, where instructional technologies are in use, the roles of instructors to organise the course, facilitate the discourse, direct the cohesion are overwhelmed by the technology-enhanced learning media. This explains the weakened influence of the teaching presence on cognitive presence.

\section{Attributes determining learning effectiveness in BL and NBL settings Self-directed learning and cognitive presence}

Self-directed learning has significant and direct impacts on the cognitive presence of students in the BL setting, while it does not have a direct impact on the cognitive presence in the NBL setting. In the BL setting, students are expected to direct themselves in learning on the online platforms, whereas teachers in the face-to-face NBL setting lead them. Enhancing student ability to control and to direct for understanding helps students learn more actively in exploring course content and ideas. The BL setting allows students to construct and confirm meaning through reflection on their own. In the NBL setting, teachers play the role of directing, explaining, and pace controlling, which makes the learning effectiveness less dependent on student self-directed behaviour.

\section{Self-directed learning, technology readiness and learning motivation}

Self-directed learning and technology readiness have a positive influence on learning motivation in $\mathrm{BL}$, whereas in the NBL learning environment only technology readiness 
influences learning motivation. The results imply that students who are more self-directed and with active attitudes toward technology-based products are more motivated in adopting online learning strategies and achieving their learning goals. In the NBL setting, learning motivation is influenced by technology readiness, but not self-directed learning. This implies that web-based learning technology can be a complementary extension of the traditional classroom teaching for inducing self-directed learning effects which in return, can influence learning motivation. It is therefore meaningful to integrate and optimise online and offline course design to reduce students' difficulty in adopting the learning technologies, with the aim of enhancing student learning motivation.

\section{Learning motivation, teaching presence and social presence}

Learning motivation is found positively influencing the social presence in both the $\mathrm{BL}$ and NBL teaching environments, where learning motivation represents the personal goal orientation that a student brings to a course of study (Lynch \& Dembo, 2004). Students with stronger learning motivation will engage more in the learning process and discuss more with group members for the idea discussion and content understanding. This explains the positive influence of learning motivation on teaching presence in both the BL and NBL setting.

\section{Technology readiness and teaching presence}

Technology readiness plays a more important role in influencing teaching presence in the BL learning environment than the NBL learning environment while both are statistically significant. Students' intention to adopt web-based learning technologies determines students' attitude to learning behaviour and perceived behavioural control. Students who are readier to adopt the web-based learning approach understand the online and offline course design better and are more aware of teaching presence while teaching presence is critical to the course and facilitation design. Our results, therefore, provide implications that course designers need to consider technology readiness when adopting BL teaching approach, for more effective teaching presence.

\section{Conclusions and future study}

In this study, we investigate the roles of self-directed learning, technology readiness, and student motivation in BL and NBL settings and their impacts on student's perception of the three presences from the $\mathrm{CoI}$ framework. The results show that the $\mathrm{BL}$ environment is better than the NBL environment in providing learning facilitation. The results from structural modelling imply that self-directed learning plays a vital role in influencing the cognitive presence, while in the NBL environment it does not. Course designers and instructors shall recognise the value of fostering students' self-directed learning in a more flexible learning context. The impact of social presence on the other two presence indicates the importance of emotionally and socially engaging students in the learning process in both online and offline learning scenarios. Technology readiness has a stronger positive influence on teaching presence in the BL setting compared to the NBL setting. Prior training or briefing of learning technologies or platforms would potentially improve students' perception of teaching presence. 


\section{Limitation of study}

Though the sample size was not that big due to the restricted enrolment number for the BL classes and was only offered to a selected group of students of the same background for the better control of the experiment. Given the above constraints, and with a systematic controlled setting, the sample sizes of 102 and 121 of BL and non-BL students respectively, is considered acceptable for providing insights for the specific study.

We expect to extend the study to more selected BL classes further. Due to the resource limit of this study, other types of evidence, for instance, the students' system usage data, are not incorporated here.

\section{Contributions}

The findings in our study reveal the impacts of self-directed learning, technology readiness and learning motivation on the learning effectiveness in the blended learning environment and the non-blended learning environment. This study expands the literature in blended learning and its influencing factors which have not been sufficiently explored. By comparing the interdependences in different learning settings, our study provides empirical evidence and insights for educators for proper instructional strategy adoption in both online and offline teaching, to enhance the perceived social, teaching, and cognitive presences leading to improved learning outcomes.

\section{Acknowledgements}

The publication of this paper is supported by the Natural Science Foundation of China (Grant Nos. 71571120).

Professor Ben Niu is the second corresponding author of this paper.

Funding

This study is supported by the Natural Science Foundation of China (Grant Nos. 71571120).

Availability of data and materials

No data is available.

About the authors

Dr. Shuang Geng is currently a Postdoctoral Researcher at School of Management, Shenzhen University. She obtained her PhD degree at the System Engineering and Engineering Management department of City University of Hong Kong. Her research interests include workplace knowledge recommendation, organizational learning, and project management in the context of China's electronics manufacturing industry, designing and developing online learning systems for higher education, and tracking and analyzing educational data. Her research papers appear in "Project Management Journal", "The Organizational Learning", "Knowledge Management: An International Journal", "International Journal of Technology and Design Education".

Dr. Kris Law is currently an Associate Professor at the School of Engineering, Deakin University, Australia. Prior to her joining Deakin University, she was a lecturer at the Department of Industrial and Systems Engineering, Hong Kong Polytechnic University. She currently also holds a Docentship (adjunct professorship) in the Department of Industrial Engineering and Management, Oulu University in Finland. Her expertise lies in Organizational Learning and Development, Technology and Innovation Management, Technology-based Entrepreneurship, Project Management and Engineering Education.

Dr. Law undertook a post-doctoral research scholarship and was a visiting researcher at the Graduate Institute of Industrial Engineering, National Taiwan University (2009-2011).

Professor Ben Niu is currently working at Management Science department at School of Management, Shenzhen University. He used to be Visiting Professor of Arizona State University, Hong Kong University, Hong Kong Polytechnic University, China The Academy of Sciences, Victoria University of Wellington, New Zealand. He has been granted 5 national natural science funds, published more than 100 academic papers, and published 3 books. His research interests include big data analysis and processing, learning recommendation systems, entrepreneurship education, financial engineering and business intelligence, swarm intelligence theory and application, image processing, feature extraction, artificial intelligence.

\section{Authors' contributions}

KMYL carried out the empirical investigation and SG wrote the first draft of the manuscript. KMYL and SG participated in designing the empirical investigation protocol, structure and review the manuscript. BN participated in finalizing the draft. All authors read and approved the final manuscript. 


\section{Publisher's Note}

Springer Nature remains neutral with regard to jurisdictional claims in published maps and institutional affiliations.

\section{Author details}

${ }^{1}$ College of Management, Shenzhen University, Shenzhen, China. ${ }^{2}$ School of Engineering, Deakin University, Geelong, Australia.

Received: 20 December 2018 Accepted: 25 April 2019

Published online: 21 May 2019

\section{References}

Aizen, I. (1991). The theory of planned behavior. Organizational Behavior and Human Decision Processes, 50, 179-211.

Akyol, Z., \& Garrison, D. R. (2008). The development of a community of inquiry over time in an online course: Understanding the progression and integration of social, cognitive and teaching presence. Journal of Asynchronous Learning Networks, 12(3-4), 3-22

Annand, D. (2011). Social presence within the community of inquiry framework. International Review of Research in Open and Distance Learning, 12(5), 40-56.

Arbaugh, J. B. (2007). An empirical verification of the community of inquiry framework. Journal of Asynchronous Learning Networks, 11(1), 73-85.

Arbaugh, J. B., Cleveland-Innes, M., Diaz, S. R., Garrison, D. R., Ice, P., Richardson, J. C., \& Swan, K. P. (2008). Developing a community of inquiry instrument: Testing a measure of the community of inquiry framework using a multi-institutional sample. The Internet and Higher Education, 11(3-4), 133-136.

Archibald, D. (2010). Fostering the development of cognitive presence: Initial findings using the community of inquiry survey instrument. Internet \& Higher Education, 13(1-2), 73-74.

Barnard-Bark, L., Burley, H., \& Crooks, S. M. (2010). Explaining youth mentoring behavior using theory of planned behavior perspective. International Journal of Adolescence and Youth, 15, 365-379.

Boelens, R., De Wever, B., \& Voet, M. (2017). Four key challenges to the design of blended learning: A systematic literature review. Educational Research Review, 22, 1-18.

Broadbent, J. (2017). Comparing online and blended learner's self-regulated learning strategies and academic performance. The Internet and Higher Education, 33, 24-32.

Che-Ha, N., Mavondo, F. T., \& Mohd-Said, S. (2014). Performance or learning goal orientation: Implications for business performance. Journal of Business Research, 67(1), 2811-2820.

Cheon, J., Lee, S., Crooks, S. M., \& Song, J. (2012). An investigation of mobile learning readiness in higher education based on the theory of planned behavior. Computers \& Education, 59(3), 1054-1064.

Chin, W. W. (1998). The partial least squares approach to structural equation modeling. Modern Methods for Business Research, 295(2), 295-336.

Cho, M. H., Kim, Y., \& Choi, D. H. (2017). The effect of self-regulated learning on college students' perceptions of community of inquiry and affective outcomes in online learning. Internet \& Higher Education, 34, 10-17.

Collis, B., \& Moonen, J. (2012). Flexible learning in a digital world: Experiences and expectations. London and New York: Routledge, Taylor \& Francis Group.

Compeau, D., \& Higgins, C. (1995). Computer self efficacy: Development of a measure and initial test. Management Information Systems Quarterly, 19(1), 9.

Demir, O. (2015). The investigation of e-learning readiness of students and faculty members: Hacettepe University Faculty of Education example [Master Thesis]. Ankara: Hacettepe University.

Diep, A. N., Zhu, C., Struyven, K., \& Blieck, Y. (2017). Who or what contributes to student satisfaction in different blended learning modalities? British Journal of Educational Technology, 48(2), 473-489.

Duphorne, P. L., \& Gunawardena, C. N. (2005). The effect of three computer conferencing designs on critical thinking skills of nursing students. American Journal of Distance Education, 19(1), 37-50

Dziuban, C., \& Moskal, P. (2001). Evaluating distributed learning in metropolitan universities. Metropolitan Universities, 12(1), 41-49.

Fahnoe, C., \& Mishra, P. (2013). Do 21st century learning environments support self-directed learning? Middle school students' response to an intentionally designed learning environment. In Society for information technology \& teacher education international conference, (pp. 3131-3139). Chesapeake: Association for the Advancement of Computing in Education (AACE).

Fairchild, A. J., Jeanne-Horst, S., Finney, S. J., \& Barron, K. E. (2005). Evaluating existing and new validity evidence for the academic motivation scale. Contemporary Educational Psychology, 30(3), 331e358.

Felder, R. M., Woods, D. R., Stice, J. E., \& Rugarcia, A. (2000). The future of engineering education II. Teaching methods that work. Chemical Engineering Education, 34(1), 26-39.

Findik, C., \& Ozkan, S. (2013). A model for instructors' adoption of learning management systems: Empirical validation in higher education context. Turkish Online Journal of Educational Technology, 12(2), 13-25.

Fornell, C., \& Larcker, D. F. (1981). Structural equation models with unobservable variables and measurement error: Algebra and statistics.

Fredricks, J. A., Blumenfeld, P. C., \& Paris, A. H. (2004). School engagement: Potential of the concept, state of the evidence. Review of Educational Research, 74(1), 59-109.

Freeman, S., Eddy, S. L., McDonough, M., Smith, M. K., Okoroafor, N., Jordt, H., et al. (2014). Active learning increases student performance in science, engineering, and mathematics. Proceedings of the National Academy of Sciences, 111(23), $8410 \mathrm{e} 8415$

Garrison, D. R., \& Akyol, Z. (2015). Toward the development of a metacognition construct for communities of inquiry. The Internet and Higher Education, 24, 66-71.

Garrison, D. R., Anderson, T., \& Archer, W. (2000). Critical inquiry in a text-based environment: Computer conferencing in higher education. The Internet and Higher Education, 2(2-3), 87-105. 
Garrison, D. R., \& Arbaugh, J. B. (2007). Researching the community of inquiry framework: Review, issues, and future directions. The Internet and Higher Education, 10(3), 157-172.

Garrison, D. R., \& Cleveland-Innes, M. (2005). Facilitating cognitive presence in online learning: Interaction is not enough. The American Journal of Distance Education, 19(3), 133-148.

Garrison, R., \& Kanuka, H. (2004). Blended learning: Uncovering its transformative potential in higher education. Internet and Higher Education, 7, 95-105.

Gilbert, N., \& Driscoll, M. (2002). Collaborative knowledge building: A case study. Educational Technology Research and Development, 50, 59-79.

Graham, C. R. (2013). Emerging practice and research in blended learning. In Handbook of distance education, (vol. 3, pp. 333350).

Graham C.R. 2013. Emerging practice and research in blended learning. In M.G. Moore (Ed), Handbook of distance education (3rd ed). New York. Routledge.

Gulek, J. C., \& Demirtas, H. (2005). Learning with technology: The impact of laptop use on student achievement. Journal of Technology, Learning, and Assessment, 3(2).

Hafiz, B., \& Shaari, J. A. N. (2013). Confirmatory factor analysis (CFA) of first order factor measurement model-ICT empowerment in Nigeria. International Journal of Business Management and Administration, 2(5), 081-088.

Hao, Y. (2016). Exploring undergraduates' perspectives and flipped learning readiness in their flipped classrooms. Computers in Human Behavior, 59, 82-92.

Henseler, J., \& Sarstedt, M. (2013). Goodness-of-fit indices for partial least squares path modeling. Computational Statistics, 1-16.

Hong, C., Hwang, M., Liu, H., \& Chen (2014). Using a "prediction- observationexplanation" inquiry model to enhance student interest and intention to continue science learning predicted by their internet cognitive failure. Computers \& Education, 72, 110e120.

Horton, W. (2006). E-learning by design. San Francisco: Pfeiffer.

Hwang, A., \& Arbaugh, J. B. (2006). Virtual and traditional feedback-seeking behaviors: Underlying competitive attitudes and consequent grade performance. Decision Sciences Journal of Innovative Education, 4, 1-28.

Jossberger, H., Brand-Gruwel, S., Boshuizen, H., \& Wiel, M. (2010). The challenge of self-directed and self-regulatSed learning in vocational education: A theoretical analysis and synthesis of requirements. Journal of Vocational Education and Training, $62(4), 415 e 440$.

Ke, F. (2010). Examining online teaching, cognitive, and social presence for adult students. Computers \& Education, 55, 808-820.

Khan, I. M. (2009). An analysis of the motivational factors in online learning. Doctoral dissertation. Arizona: University of Phoenix.

Kizilcec, R. F., Pérez-Sanagustín, M., \& Maldonado, J. J. (2017). Self-regulated learning strategies predict learner behavior and goal attainment in massive open online courses. Computers \& Education, 104, 18-33.

Law, K. M., \& Breznik, K. (2017). Impacts of innovativeness and attitude on entrepreneurial intention: Among engineering and non-engineering students. International Journal of Technology and Design Education, 27(4), 683-700.

Law, K. M., \& Geng, S. (2018). How innovativeness and handedness affect learning performance of engineering students? International Journal of Technology and Design Education, 1-18. https://doi.org/10.1007/s10798-018-9462-3

Law, K. M., Lee, V. C., \& Yu, Y. T. (2010). Learning motivation in e-learning facilitated computer programming courses. Computers \& Education, 55(1), 218-228.

Lee, C. B., \& Teo, T. (2010). Fostering self-directed learning with ICT. In C. S. Chai, \& Q. Wang (Eds.), ICT for selfdirected and collaborative learning, (pp. 39-51). Singapore: Pearson.

Lee, K., Tsai, P. S., Chai, C. S., \& Koh, J. H. L. (2014). Students' perceptions of self-directed learning and collaborative learning with and without technology. Journal of Computer Assisted Learning, 30(5), 425-437.

Lim, D. H. (2004). Cross cultural differences in online learning motivation. Educational Media International, 41(2), $163 \mathrm{e} 173$.

Littlejohn, A., \& Pegler, C. (2007). Preparing for blended e-learning. London: Routledge.

Liu, Y., Li, H., \& Carlsson, C. (2010). Factors driving the adoption of m-learning: An empirical study. Computers \& Education, 55(3), 1211-1219.

Long, H. B. (1994). Resources related to overcoming resistance to self-direction in learning. New Directions for Adult and Continuing Education, 64, 13-21.

Lynch, R., \& Dembo, M. (2004). The relationship between self-regulation and online learning in a blended learning context. The International Review of Research in Open and Distributed Learning, 5(2). https://doi.org/10.19173/irrodl.v5i2.189

Martyn, M. (2003). The hybrid online model: Good practice. Educause Quarterly, 1, 18-23.

Milligan, C., \& Littlejohn, A. (2014). Supporting professional learning in a massive open online course. The International Review of Research in Open and Distributed Learning, 15(5). https://doi.org/10.19173/irrodl.v15i5.1855

Moftakhari, M. M. (2013). Evaluating e-learning readiness of faculty of letters of Hacettepe. Master thesis. Ankara: Hacettepe University.

Mtebe, J. S., \& Raisamo, R. (2014). Challenges and instructors' intention to adopt and use open educational resources in higher education in Tanzania. International Review of Research in Open and Distance Learning, 15(1), 249-271.

Ngan, S. C., \& Law, K. M. (2015). Exploratory network analysis of learning motivation factors in e-learning facilitated computer programming courses. The Asia-Pacific Education Researcher, 24(4), 705-717.

Parasuraman, A. (2000). Technology readiness index (TRI) a multiple-item scale to measure readiness to embrace new technologies. Journal of Service Research, 2(4), 307-320.

Parasuraman, A., \& Colby, C. L. (2015). An updated and streamlined technology readiness index: TRI 2.0. Journal of Service Research, 18(1), 59-74.

Piskurich, G. M. (2003). Preparing learners for e-learning. San Francisco: Wiley.

Porter, W. W., Graham, C. R., Bodily, R. G., \& Sandberg, D. S. (2016). A qualitative analysis of institutional drivers and barriers to blended learning adoption in higher education. The Internet and Higher Education, 28, 17-27.

Prensky, M. (2001). Digital natives, digital immigrants part 1. On the horizon, 9(5), 1-6.

Rovai, A. P., \& Jordan, H. (2004). Blended learning and sense of community: A comparative analysis with traditional and fully online graduate courses. The International Review of Research in Open and Distributed Learning, 5(2). https://doi.org/10. 19173/irrodl.v5i2.192 
Sana, F., Weston, T., \& Cepeda, N. J. (2013). Laptop multitasking hinders classroom learning for both users and nearby peers. Computers \& Education, 62, $24 \mathrm{e} 31$.

Sanchez, G. (2013). PLS path modeling with R. Berkeley: Trowchez editions, (p. 383).

Shea, P., \& Bidjerano, T. (2009). Community of inquiry as a theoretical framework to foster "epistemic engagement" and "cognitive presence" in online education. Computers \& Education, 52(3), 543-553.

Shea, P., Hayes, S., Vickers, J., Gozza-Cohen, M., Uzuner, S., Mehta, R., et al. (2010). A re-examination of the community of inquiry framework: Social network and content

Shea, P., Li, C. S., Swan, K., \& Pickett, A. (2005). Developing learning community in online asynchronous college courses: The role of teaching presence. Journal of Asynchronous Learning Networks, 9(4), 59-82.

Shouping, H., \& Kuh, G. D. (2001). Computing Experience and Good Practices in Undergraduate Education: Does the Degree. of Campus" Wiredness" Matter?. Education Policy Analysis Archives, 9(49).

Stockwell, B. R., Stockwell, M. S., Cennamo, M., \& Jiang, E. (2015). Blended learning improves science education. Cell, 162(5), 933-936.

Sarstedt, M., Ringle, C. M., \& Hair, J. F. (2017). Partial least squares structural equation modeling. Handbook of market research, $1-40$.

Tabor, S. (2007). Narrowing the distance: Implementing a hybrid learning model for information security education. The Quarterly Review of Distance Education, 8(1), 47-57.

Teo, T., Tan, S. C., Lee, C. B., Chai, C. S., Koh, J. H. L., Chen, W. L., \& Cheah, H. M. (2010). The self-directed learning with technology scale (SDLTS) for young students: An initial development and validation. Computers \& Education, 55, 1764-1771.

Tullis, J. G., \& Benjamin, A. S. (2011). On the effectiveness of self-paced learning. Journal of Memory and Language, 64(2), $109-118$.

Vanslambrouck, S., Zhu, C., Lombaerts, K., Philipsen, B., \& Tondeur, J. (2018). Students' motivation and subjective task value of participating in online and blended learning environments. The Internet and Higher Education, 36, 33-40.

Vaughan, N. (2007). Perspectives on blended learning in higher education. International Journal on ELearning, 6(1), 81-94.

Wang, Y., Wu, M., \& Wang, H. (2009). Investigating the determinants and age and gender differences in the acceptance of mobile learning. British Journal of Educational Technology, 40(1), 92-118.

Williams, E. A., Duray, R., \& Reddy, V. (2006). Teamwork orientation, group cohesiveness, and student learning: A study of the use of teams in online distance education. Journal of Management Education, 30, 592-616.

Yilmaz, R. (2016). Knowledge sharing behaviors in e-learning community: Exploring the role of academic self-efficacy and sense of community. Computers in Human Behavior, 63, 373e382.

Zimmerman, B. J. (2000). Attaining self-regulation: A social-cognitive perspective. In M. Boekaerts, P. R. Pintrich, \& M. Zeidner (Eds.), Handbook of self-regulation, (pp. 13-39). San Diego: Academic.

\section{Submit your manuscript to a SpringerOpen ${ }^{\circ}$ journal and benefit from:}

- Convenient online submission

- Rigorous peer review

- Open access: articles freely available online

High visibility within the field

- Retaining the copyright to your article

Submit your next manuscript at $>$ springeropen.com 